\title{
HADIS TEMATIK ANTROPOMORFISME
}

\author{
Oleh : Uqbatul Khoir Rambe, MA.
}

\begin{abstract}
The word "anthropomorphism" is derived from English "anthropomorphism" which comes from the Greek "anthropos" (human) and "morphe" (form). In Islamic teachings, anthropomorphism is identified with "tasybîh" or "tajassum". Tashbîh means to resemble something with something else. In theological terms, tasybîh means the likeness of God with humans in the form and attributes of Him. Whereas tajassum means the depiction of the body of God as found in humans. That doctrinal anthropomorphism is a necessity and is evident both in the hadith and the Koran. The amount even so much, can reach hundreds. From the hadith of the Messenger of Allah it was found that the holy riots were claimed by Bukhori and Muslim. When viewed from Mukhorrij it is strongly believed that the hadith is very true, and there is no reason to reject it. While at the level of thought, both in sarah and in the opinions of scholars, theologians and Sufis found their thoughts varied.Each argues that supports their thinking. Nothing can take precedence over the others, because all interpretations are intended to establish the right acceptance of Allah SWT. Wallohu a bus showab.
\end{abstract}

Keywords: Anthropomorphism, Hadith.

\section{A. Pendahuluan}

Tuhan dan manusia tentu saja berbeda. Tuhan sebagai pencipta, sedangkan manusia adalah ciptaan-Nya. Namun dalam banyak ayat Allah mengatakan bahwa Ia mempunyai tangan, wajah, singgasana dan lain sebagainya. Pada ayat lain "sebaliknya" Tuhan mengatakan bahwa tidak ada yang surupa dengan dia. Hal tersebut membuat manusia bingung lalu berasumsi dan berimajinasi dalam membayangkan bentuk Tuhan tersebut. Masalah ini di dalam kajian islam disebut dengan antropomorfisme. Dalam bahasa arab sering diungkapkan bengan mujassimah dan musabbibah.

Tentang antropomorfisme tersebut tidak hanya terdapat di dalam al-Quran. Di dalam hadispun ternyata hadis-hadis antropomorfisme itu ditemukan ratusan. 
Dalam kaitan itu, penulis akan menggali makna hadist antripomorfisme tersebut secara metode tematik. Diharapkan dengan kajian seperti ini akan memberikan keterangan dan pencerahan.

\section{B. Pengertian Antropomorfisme}

Kata "antropomorfisme" terambil dari bahasa Inggris "anthropomorphism" yang berasal dari bahasa Yunani "anthropos" (manusia) dan "morphe" (bentuk). Dari sini lahir beberapa definisi, di antaranya :

1) Gambaran tentang Tuhan, dewa/dewi, atau kekuatan-kekuatan alam sebagai memiliki bentuk dan ciri-ciri manusiawi. Memberikan sifat-sifat manusia kepada Ilahi. Allah ataupun para dewata dipahami dalam bentuk manusia.

2) Keyakinan bahwa Tuhan, atau dewa/dewi, memiliki ciri-ciri yang serupa dengan ciri-ciri manusia. Misalnya, kesadaran, kehendak, dan emosi. Suatu bentuk ekstrem dari antropomorfisme mempertahankan bahwa Tuhan atau dewa/dewi ada dalam bentuk manusia tetapi lebih sempurna dan lebih berkuasa.

3) Memindahkan bentuk dan ciri-ciri manusia kepada kekuatan-kekuatan luar alam dan mempertalikannya dengan makhluk-makhluk mistik (para dewa, roh-roh, dst).

4) Mempresentasikan Tuhan, dewa-dewa, atau kekuatan alam seakan memiliki bentuk atau atribut-atribut manusiawi.

5) Dalam filsafat istilah ini merupakan aliran yang menerapkan sifat-sifat manusia pada sesuatu selain manusia, misalnya pada alam. Istilah ini dipakai untuk menggambarkan Tuhan dengan kata-kata atau istilah-istilah manusiawi.

Di dalam ajaran Islam, antropomorfisme, diidentikkan dengan "tasybîh” atau "tajassum", sebagaimana yang terlihat pada tulisan Harun Nasution ketika membahas tentang sifat-sifat jasmani bagi Allah yang tertera di dalam al-Qur'an dan Hadis. ${ }^{2}$ Tasybîh berarti menyerupakan sesuatu dengan sesuatu yang lain. Dalam pengertian teologis, tasybîh berarti penyerupaan Allah dengan manusia dalam bentuk dan sifatsifat-Nya. Sedangkan tajassum berarti penggambaran kebertubuhan Allah seperti yang terdapat pada manusia.

${ }^{1}$ Lorens Bagus, Kamus Filsafat, (Jakarta : Gramedia, 1996), h. 59

${ }^{2}$ Harun Nasution, Teologi Islam: Aliran-aliran, Sejarah, Analisa Perbandingan (Jakarta: UI Press, 1986), h. 137-139. 
Pada substansinya, tajassum dalam teologi Islam semakna dengan tasybîh, yaitu menyerupakan Tuhan dengan makhluk. Sebab, pada tajassum ditemukan adanya keyakinan bahwa Tuhan memiliki jasad atau anggota tubuh sebagaimana manusia. Hal ini sesuai dengan yang disebutkan oleh al- Syahrastani sebagai berikut, "Demikianlah! sesungguhnya menyerupakan Tuhan dengan makhluk adalah menjadikannya setara di dalam bentuk dan keadaannya, demikian pula bahwa makhluk memiliki jism (tubuh), maka Tuhan juga memiliki jism dan memiliki sifat jismiyah. Karena makhluk membutuhkan ruang untuk jism-nya maka kelompok Musyabbihah pun menetapkan jism bagi Allah dengan ukuran tertentu dan juga memberikan batasan tempatnya. Kedua istilah ini dalam satu standar (makna) dan menetapkan keduanya dalam makna yang identik". ${ }^{3}$

Jika antropomorfisme dipahami sebagai tasybîh dalam definisi di atas, maka seluruh mainstream aliran teologi Islam yang tergolong ke dalam Ahli Sunnah, tentu akan menolaknya. Sebab hal itu akan bertentangan dengan ajaran al-Qur'an dan Sunnah itu sendiri. Penggambaran dan tindakan mempersamakan Tuhan dengan manusia, baik pada zat maupun pada sifat-Nya merupakan kemusyrikan. Di dalam alQur'an dengan tegas dikatakan bahwa tidak ada sesuatu apapun yang sama dengan Allah. Karena itu, penggunaan term Antropomorfisme dalam ajaran Islam tanpa penjelasan yang khusus tentu tidak dapat diterima dari mainstream Ummat Islam.

\section{A. Hadis-hadis Antropomorfisme}

Ada ratusan hadis yang berkaitan dengan pembahasan di atas antara lain adalah:

\section{Hadis tentang melihat Tuhan}

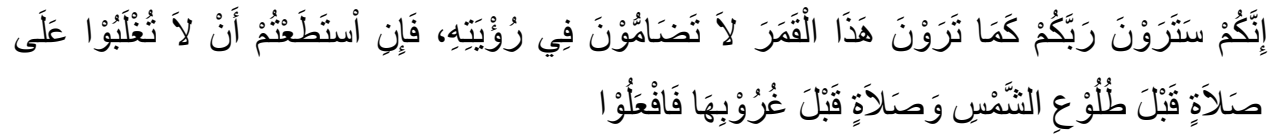

Artinya: Sesunggubnya kalian akan melihat Rabb kalian sebagaimana kalian melihat bulan ini (dalam permulaan hadits, diceritakan; waktu itu Nabi Shallallahu 'alaibi wa sallam sedang melihat bulan yang tengah purnama). Kalian tidak berdesak-desakan ketika melihat-Nya (ada yang membaca la tudhamuna tanpa tasydid dan di dhammah ta'nya, artinya: kalian tidak akan

${ }^{3}$ Lihat al-Syahrastani, al-Milâl wa al-Nihâl (t.t.p.: Dâr al-Fikr, t.t.), h. 105. 
ditimpa kesulitan dalam melihat-Nya). Oleb karena itu, jika kalian mampu, untuk tidak mengabaikan shalat sebelum terbit matahari (Subub) dan shalat sebelum terbenam matahari (Ashar), maka kerjakanlah. ${ }^{4}$

\section{Hadis tentang tangan Allah}

Dalam riwayat Bukhari dan Muslim dari Abu Hurairah, Rasulullah bersabda:

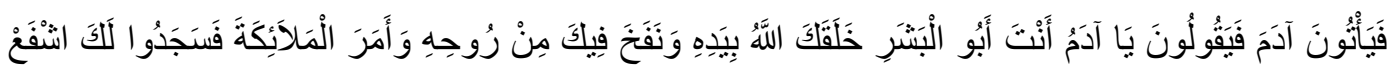

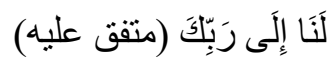

Artinya: Rasulullah صلى الله عليه وسلم bersabda: Mereka menemui Adam dan berkata: "Wabai Adam engkau adalab Bapaknya manusia, Allab telab menciptakan engkau dengan Tangan-Nya, meniupkan rub dalam dirimu, dan Allah telah memerintabkan para malaikat untuk bersujud kepadamu, mintakanlah syafaat untuk kami kepada Rabbmu... (HR. Bukhari dan Muslim) $)^{5}$

\section{Jari-jemari Allah}

صلى الله عليه وسلم Diriwayatkan dari 'Amr bin Al 'Ash, bahwasanya Rasulullah bersabda:

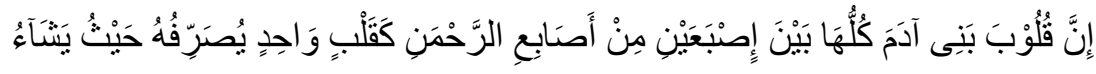

Artinya; "Sesunggubnya hati Bani Adam selurubnya berada di antara dua jari dari jari arRahman (Allab) seperti hati yang satu. Allab memalingkannya sekehendaknya." (HR. Muslim)

\section{Telapak tangan Allah}

${ }^{4}$ Shahih Bukhari, Fathul Bari, XIII/419, hadits no. 7434, dan Muslim Syarah Nawawi, tahqiq Khalil Ma'mun Syiha, V/135, hadits no. 1432, Bab Fadhli Shalati Ash Shubhi Wal 'Ashri Wal Muhafazhah 'Alaihima. Hadits ini juga diriwayatkan oleh Tirmidzi, no. 2551; Shahih Sunan At Tirmidzi, III; Ibnu Majah, Shahih Sunan Ibni Majah, I, no. 147/176, h.

${ }^{5}$ Ibid, h. 310. 
Diriwayatkan dari Abu Hurairah, Rasulullah صلى الله عليه وسلم bersabda:

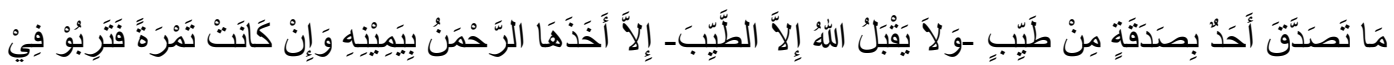

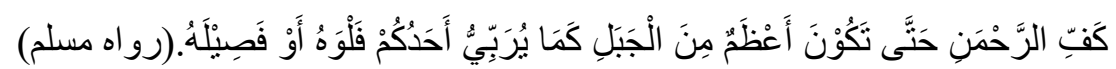
Artinya: "Tidaklah seseorang bershadaqah dengan shadaqah yang baik -dan Allah tidak menerima kecuali yang baik_-kecuali Allah yang Maha Rahman akan mengambilnya dengan Tangan kanan-Nya, walaupun sebuah kurma, Allah akan membesarkannya di Telapak. Tangan Allah yang Maha Rahman bingga menjadi lebih besar dari gunung, sebagaimana salah seorang kalian membesarkan anak kambing atau anak unta." (HR. Bukhari dan Muslim)

\section{Lengan Allah}

Didalam riwayat yang agak panjang, Rasulullah صلى الله عليه و سلم bersabda:

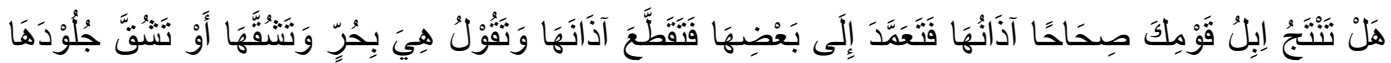

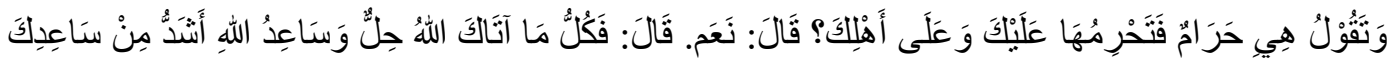

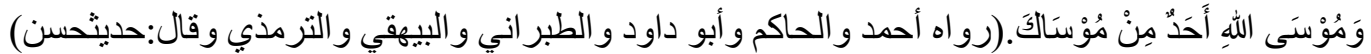

Artinya: "Apakah unta-unta kaummu yang labir dalam keadaan sehat dan utuh telingatelinganya kemudian kamu dengan sengaja mengambil pisau dan memotong telinga-telinganya dan kamu katakan unta-unta ini merdeka?!. Dan kamu robek telinga-telinganya atau kamu cacati kulit-kulitnya, kemudian kamu katakan unta-unta ini haram? Kemudian kamu haramkan untuk dirimu dan keluargamu?! Dia menjawab: "Ya". Maka Rasulullah صلى الله علبه وسلى bersabda: "Sungguh seluruh apa yang diberikan Allah kepadamu (dari binatang ternak itu) adalah halal. Ingat Lengan Allah lebih kuat dari lenganmu dan Pisau Allah lebih tajam dari pisaumu.” (HR. Ahmad, Hakim, Abu Dawud, Baihaqi, Thabrani dan Tirmidzi. Tirmidzi berkata: "Hadits Hasan Shahih).

\section{Hadis tentang wajah Allah}

Mengenai wajah Allah banyak sekali hadis yang berbicara mengenai hal tersebut. Karena begitu banyaknya maka di dalam makalah ini disebutkan nomornya saja. Di dalam HR. Bukhari : 54, 407, 431, 113, 1197, 1213, 2917, 3153, 3608, 3623, 3643, 3741, 3773, 3990, 3991, 4057, 4982, 5236, 5599, 5635, 5817, 5861, 5896, 5943,

\footnotetext{
${ }^{6}$ Lihat Tahqiq Kitab Asma' wa Shifat oleh Al-Baihaqi, h. 170.
} 
5967, 6236, 6425. Sedangkan di dalam HR. Muslim : 828, 1052, 1562, 1759, 1760, 3076,5297

Salah satunya adalah do'a Rasulullah shallallabu 'alaibi wa sallam berbunyi sebagai berikut:

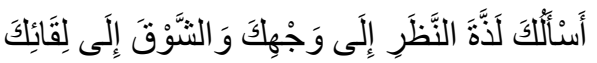

Artinya: "Aku meminta kepada-Mu (ya Allah) kenikmatan memandang wajah-Mu (di akbirat nanti) dan aku meminta kepada-Mu kerinduan untuk bertemu dengan-Mu (sewaktu di dunia).

\section{B. Kedudukan/ Status Hadis}

1. Melihat Allah

Syaikh Shalih bin Fauzan Al-Fauzan menerangkan bahwa hadis di atas tentang melihat Allah semata-mata dengan pandangan mata kepala adalah mutawatir.

Banyak hadis yang semakna dengan hadis disebutkan di atas seperti yang diriwayatkan Qotadah. Ibnu Taimiyyah dan banyak ulama hadis menshahihkan tersebut. Abu Ya'la (meninggal tahun $458 \mathrm{H}$ ) dalam kitabnya Ibthal at-Ta'wilat menyebutkan bahwa di antara yang menshahihkan hadits ini adalah ath-Thabrani dan Imam Ahmad. Ibnu shadaqah al-Hafidz menyatakan bahwa barangsiapa yang tidak mempercayai hadits Qotadah (hadits tadi) maka ia termasuk orang zindiq. Abu Zur'ah menyatakan bahwa orang yang mengingkari hadits Qatadah dari Ikrimah dari Ibnu Abbas radhiyallahu anhuma (hadits tadi) maka ia adalah orang mu'tazilah. ${ }^{8}$

2. Hadis tentang tangan Allah

Hadi mengenai tangan yang disebutkan di atas adalah hadis shahih dan diriwatkan oleh Bukhari dan Muslim tanpa penyebutan tangan kiri. ${ }^{9}$

3. Hadis tentang Jari-jemari Allah

Hadits ini disahihkan al-Albani. ${ }^{10}$

${ }^{7}$ Lihat Syarah Al Aqidah Al Wasithiyah, Syaikh Shalih Al Fauzan, hlm. 140, terbitan Maktabah Al Ma'arif Li An Nasyr Wat Tauzi'- Riyadh, Cet. VI-1413 H/1993 M, h. 121.

${ }^{8}$ Bayaan Talbiis Al-Jahmiyah Fi Ta'sis Bida'ihim al-Kalamiyah 1/143-145, h. 230.

${ }^{9}$ Mizaanul I'tidal (3/192) dan Tahdzibut Tahdzib (7/437)

${ }^{10}$ Lihat Sahih Sunan Tirmidzi, 3/447 
4. Hadis tentang wajah Allah

Hadis tentang wajah Allah ini sangat banyak sekali di dalam kitab Bukhori dan Muslim. Pada kitab HR. Bukhari : 54, 407, 431, 113, 1197, 1213, 2917, 3153, 3608, 3623, 3643, 3741, 3773, 3990, 3991, 4057, 4982, 5236, 5599, 5635, 5817, 5861, 5896, 5943, 5967, 6236, 6425, Sedangakan pada Muslim : 828, 1052, 1562, 1759, $1760,3076,5297$.

\section{Penjelasan Hadis}

1. Hadis tentang melihat Allah

Menurut Imam Ibnu Hajar Al Asqalani, dalam mensyarah hadits-hadits yang dipaparkan oleh Imam Bukhari dan Imam Muslim menegaskan secara jelas, bahwa kaum mu'minin di akhirat kelak akan melihat Allah semata-mata dengan pandangan mata. ${ }^{11}$

Imam Nawawi mengatakan, manusia akan melihat Allah secara nyata, tidak ada keraguan dalam melihat-Nya, dan tidak pula ada kesulitan padanya, seperti halnya melihat bulan (purnama). ${ }^{12}$

Ibnu Taimiyah mengatakan bahwa melihat Tuhan dapat dilakukan manusia dengan rukyah mimpi. ${ }^{13}$ Ia menegaskan: Melihat Allah di dunia dengan mata telanjang tidak pernah terjadi pada seorang pun di dunia ini dengan kesepakatan Ulama', akan tetapi terkait Nabi shallallaahu alaihi wa sallam mayoritas ulama menyatakan bahwa Beliau tidak melihat-Nya dengan matanya sebagaimana hal itu ditunjukkan oleh Qur'an dan Sunnah. ${ }^{14}$

Selanjutnya Ibnu Taimiyyah mengatakan bahwa "rukyah" (penglihatan) walaupun pada asalnya ia sepadan (dengan hakikat sesuatu itu.) tetapi ada kalanya ia tidak sepadan. Seperti makna firman-Nya:

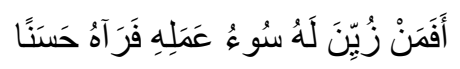

${ }^{11}$ Lihat Fathul Bari, XIII/419-433, dan Shahih Muslim Syarah Nawawi, tahqiq Khalil Ma'mun Syiha, V/134-137, h. 234.

${ }^{12}$ Syarh Shahih Muslim, Nawawi, h. 136-137.

${ }^{13}$ Bayaan Talbiis Al-Jahmiyah Fi Ta'sis Bida'ihim al-Kalamiyah 7/194.

${ }^{14}$ Al-Jawab as-Shahih liman Baddalal Diin al-Masih 3/321. 
Artinya: "Maka (Pikirkanlah) adakah orang yang dibaguskan baginya amal buruknya (oleh Syaitan lalu ia melihatnya baik)." 15

Dan Allah ta'ala berfirman:

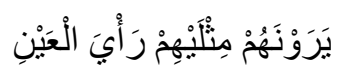

Artinya: Mereka (yang kafir itu) melihat orang-orang Islam dengan pandangan mata mereka-dua kali jumlabnya dibanding dengan mereka sendiri. ${ }^{16}$

Boleh jadi suatu persangkaan atau khayalan itu sesuai (dengan hakikat sesuatu itu) dilihat dari salah satu sudut walaupun pada realitasnya ia tidak sama dengan hakikat sesuatu itu sepenuhnya. Sebagaimana yang dilihat oleh manusia dalam mimpi mereka. Barangkali ketika terjaga mereka melihat apa yang sejenis yang dilihat dalam mimpi, ia melihat gambaran, perbuatan ataupun mendengar kata-kata sedangkan itu merupakan permisalan yang diberikan untuk hakikat dari sesuatu itu. Sebagaimana Nabi Yusuf melihat bintang-bintang, Matahari dan Bulan sujud kepadanya. Tidak diragukan bahwa ia adalah sesuatu yang digambarkan olehnya sedangkan hakikatnya adalah sujudnya kedua ibu-bapak dan saudara-saudaranya kepadanya. Berkata Nabi Yusuf:

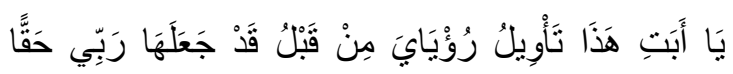

Artinya: Wahai ayabku! Inilah Dia tafsiran mimpiku dabulu. Sesunggubnya Allah telah menjadikan mimpiku itu benar. ${ }^{17}$

Begitu juga dengan 'rukyah' (mimpi) si Raja yang ditafsirkan oleh Nabi Yusuf. Si Raja telah bermimpi melihat tangkai tumbuhan dan lembu, sedangkan hakikat tafsirnya adalah kesuburan dan kemarau. Apa yang dilihatnya dalam mimpi itu adalah benar sebagaimana yang tergambar buatnya. Dengan kata lain ia memiliki takwil yang benar.

Atas dasar ini, boleh jadi seseorang itu bermimpi melihat Rabbnya serta berbicara dengan-Nya. Mimpi yang begini bisa jadi benar, namun orang itu tidak boleh beranggapan bahawa hakikat Allah adalah sebagaimana yang dilihat dalam
${ }^{15}$ Q.S Fatir : 8 .
${ }^{16}$ Q.S Ali-Imran:13.
${ }^{17}$ Q.S Yusuf:100. 
mimpinya itu. Ini karena apa yang terbayang dalam mimpi tidak harus menyamai hakikat sesuatu itu. ${ }^{18}$

Dari sini juga bisa difahami bahwa bila benar Ibnu Taimiyyah menetapkan bahwa Nabi shallallahu alaihi wa sallam bermimpi melihat Allah ta'ala dalam bentuk tertentu maka ini tidak melazimkan bahwa bentuk tersebut adalah hakikat dari bentuk Allah ta'ala dan dengan demikian tidaklah tepat bila dikatakan bahwa Ibnu Taimiyyah memiliki keyakinan bahwa Allah ta'ala berbentuk pemuda dengan sifat-sifat tertentu.

2. Hadis tentang tangan dan jari-jemari Allah

Menurut Ibnu Abdil Barr dalam 'At-Tamhid, hadits mengenai tangan dan jari-jemari Allah adalah haq/benar, karena disampaikan oleh orang tsiqah (benar keimanan dan ketakwaannya serta kuat hafalannya). Hanya saja tentang penafsirannya, ia mengatakan tidak seorangpun yang mampun untuk menafsirkannya." ${ }^{19}$

Dalam Fatawa Lajnah Da'imah, 'Yang wajib adalah menetapkan apa yang telah Allah tetapkan untuk dirinya, seperti kedua tangan, kedua kaki, jari jemari dan sifat lainnya yang disebutkan dalam Al-Quran dan Sunah dengan kedudukan yang sesuai dengan kemuliaan Allah Ta'ala, tanpa dirubah, dibagaimanakan, diserupakan (dengan makhluk) dan digugurkan. Berdasarkan firman Allah Ta'ala, "Katakanlah: "Dia-lah Allah, Yang Maha Esa. Allah adalah Tuhan yang bergantung kepada-Nya segala sesuatu. Dia tiada beranak dan tidak pula diperanakkan, dan tidak ada seorangpun yang setara dengan Dia." ${ }^{20}$

3. Hadis tentang wajah Allah

Syaikh Muhammad bin Shalih Al-'Utsaimin menjelaskan: “Wajah (Allah) merupakan sifat yang terbukti keberadaannya berdasarkan dalil Al-Kitab, As-Sunnah dan kesepakatan ulama salaf." Kemudian beliau menjelaskan di dalam kitabnya yang lain: "Nash-nash yang menetapkan wajah dari Al-Kitab dan As-Sunnah tidak

\footnotetext{
${ }^{18}$ Bayaan Talbiis Al-Jahmiyah Fi Ta'sis Bida'ihim al-Kalamiyah 7/194 1/325-326.

${ }^{19}$ Diriwayatkan oleh Al-Baihaqi dalam 'Al-Asma wa Ash-Shifat', 2/198, Ibnu Abdil Barr dalam 'At-Tamhid, 7/149.

${ }^{20}$ Lihat Fatawa Lajnah Da'imah (2/376).
} 
terhitung banyaknya, semuanya menolak ta'wil kaum mu'aththilah yang menafsirkan wajah dengan arah, pahala atau dzat.

Sedangkan keyakinan yang dipegang oleh para pengikut al-Haq yaitu menetapkan bahwasanya wajah adalah sifat dan bukan dzat. Dan penetapan sifat tersebut tidaklah melahirkan konsekuensi dzat Allah ta'ala tersusun dari berbagai anggota tubuh (seperti makhluk) sebagaimana yang dikatakan oleh kaum Mujassimah. Akan tetapi sifat itu benar-benar sifat Allah yang sesuai dengan keagungan-Nya. Wajah-Nya tidak menyerupai wajah apapun. Dan wajah apapun tidak ada yang menyerupai wajah-Nya."21

\section{Pandangan Ulama,Teologi Dan Sufi Terhadap Antropomorfisme}

\section{Pandangan Ahlu Hadis}

Pandangan ahlu hadis mengenai hadis antropomorfisme ini adalah sebagai berikut: Sufyan Ibnu Uyainah mengatakan demikian:

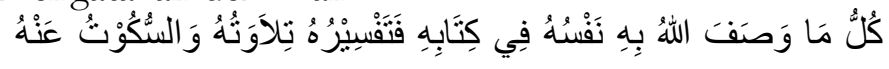
Setiap apa yang Allah sifati diri-Nya dalam kitab-Nya maka tafsirnya adalah membacanya dan diam. ${ }^{22}$

Berkata Ibnu Syihab Az-Zuhri:

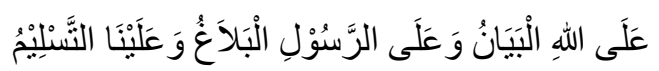

Allah yang menerangkan, rasul yang menyampaikan dan atas kita untuk menerima. ${ }^{23}$

Berkata Wahb bin Munabbih ketika ditanya oleh seorang Ja'd bin Dirham tentang asma' wa shifat:

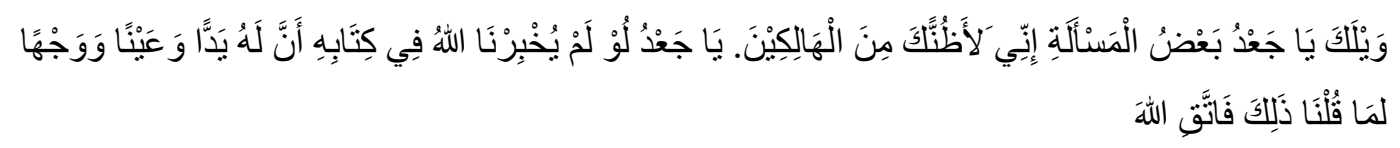

Celaka engkau wahai Ja'd karena permasalahan ini. Sungguh aku menduga engkau akan binasa. Wahai Ja'd, kalau saja Allah tidak mengabarkan dalam kitab-Nya bahwa

\footnotetext{
${ }^{21}$ Lihat Syarah 'Aqidah Wasithiyah

${ }^{22}$ Aqidatus Salaf Ashhabul Hadits, h. 248.

${ }^{23}$ Ibid, h. 249.
} 
dia memiliki tangan, mata atau wajah, tentu kamipun tidak akan mengatakannya. Bertakwalah engkau kepada Allah!"24

Berkata al-Walid ibnu Muslim: “Aku telah bertanya kepada Al Auza'i, Sufyan AtsTsauri, Malik bin Anas tentang hadits-hadits sifat dan ru'yah (tentang dilihatnya Allah pada hari kiamat), mereka semua menjawab: Langsungkanlah, sebagaimana adanya tanpa mempertanyakan seperti apa". ${ }^{25}$

Berkata Imam Malik bin Anas: "Berhati-hatilah kalian terhadap kebid'ahan.” Beliau ditanya: "Apakah bid'ah itu". Beliau menjawab: "Ahlul bid'ah adalah mereka yang membicarakan tentang nama-nama Allah, sifat-sifat-Nya, kalam Allah, ilmu Allah dan kekuasan-Nya tanpa ilmu. Mereka tidak mau diam sebagaimana diamnya para shahabat dan tabi'in terhadap masalah tersebut" ${ }^{26}$

\section{Pandangan Ulama Terhadap Antropomorfisme}

Imam Abul-Qasim Al-Ashbahani rahimahullah berkata, "Sabda Rasulullah shallallahu 'alaihi wa sallam, 'Sesungguhnya salah seorang di antara kalian datang dengan shadaqahnya lalu ia meletakkannya pada telapak tangan Ar-Rahmaan', dan sabda beliau shallallahu 'alaihi wa sallam : 'Allah meletakkan langit-langit di atas satu jari dan bumi-bumi di atas satu jari'; dan hadits-hadits yang semisal. Apabila seseorang mentadaburinya tanpa ada sikap fanatik, maka akan jelas baginya kebenaran hal itu. Iman kepadanya wajib, sedangkan membahas tentang kaifiyyah-nya adalah batil". ${ }^{27}$

Shiddiq Hasan Khan rahimahullah berkata, "Dan termasuk diantara sifat-Nya Subhanahu Wa Ta'ala : tangan kanan, telapak tangan, dan jari”. 28

\footnotetext{
${ }^{24}$ Aqidatus Salaf...., h. 190.

${ }^{25}$ Ibid, h. 249.

${ }^{26}$ Aqidatus Salaf...., h. 244.

${ }^{27}$ Al-Hujjah fii Bayaanil-Mahajjah, 2/259.

${ }^{28}$ Qathfuts-Tsamar, h. 166
} 
Al-Ajurri rahimahullah berkata, "Bab : Iman bahwa hati-hati manusia berada di antara dua jari dari jari-jari Rabb 'Azza Wa Jalla, tanpa perlu menanyakan kaifiyyahnya". 29

Al-Baghawi rahimahullah berkata, "Dan jari yang disebutkan dalam hadits merupakan sifat dari sifat-sifat Allah 'azza wa jalla. Begitu juga dengan semua hal yang disebutkan dalam al-kitab atau as-sunnah dalam perkara ini termasuk sifat-sifat Allah subhaanahu wa ta'ala seperti an-nafs, al-wajh (wajah), al-'ain (mata), al-yad (tangan), ar-rijl (kaki), al-ityaan (kedatangan), al-majii' (tiba), turun ke langit dunia, istiwaa' di atas 'Arsy, al-dhabike (tertawa), dan al-farah (gembira)". 30

Ibnu Qutaibah rahimahullah menjelaskan: “Apabila ditanyakan kepada kami : ‘Apa makna jari di sini menurutmu ?’. Maka kami katakan : Jari di sini seperti sabdanya shallallaahu 'alaihi wa sallam dalam hadits yang lain : 'Allah membawa bumi di atas satu jari', dan demikian juga dengan 'dua jari'. Tidak boleh memaknai jari di sini sebagai nikmat, seperti firman-Nya ta'ala : 'Dan mereka tidak mengagungkan Allah dengan pengagungan yang semestinya, padahal bumi seluruhnya dalam genggaman-Nya pada hari Kiamat dan langit digulung dengan tangan kanan-Nya' (QS. Az-Zumar : 67). Maka, tidak boleh mengartikan jari dengan nikmat. (Meski demikian), kami tidak mengatakan jari (Allah) seperti jari-jari kita, tangan (Allah) seperti tangan-tangan kita, genggaman (Allah) seperti genggaman-genggaman kita, karena segala sesuatu yang berasal dari-Nya 'Azza Wa Jalla - tidak menyerupai kita sedikitpun". ${ }^{31}$

Menurut Aqidah Ahlus Sunnah Wal Jama'ah dari Salaful Ummah yaitu yang terdiri dari para Sahabat, Taabi'in dan Taabi'ut Taabi'in bersama dengan orang yang mengikuti mereka dari para Imam dan para Ulama dan seterusnya dari zaman ke عزوجل zaman sampai hari kiamat, mereka semuanya mengatakan bahwa Allah mempunyai kedua tangan yang mulia sebagaimana Allah عزوجل telah memberitahukan kepada kita di dalam kitab-Nya yang mulia dan juga Rasulullah صلى di dalam sabda-sabda suci beliau dari hadits-hadits yang shahih.

\footnotetext{
${ }^{29}$ Asy-Syarii'ah, 2/115

${ }^{30}$ Syarhus-Sunnah, 1/116

${ }^{31}$ Tawiil Mukhtalafil-Hadiits, h. 245
} 


\section{Pendapat Golongan Syi'ah}

Syi'ah adalah pengikut setia yang fanatik kepada Ali dan keturunannya. ${ }^{32}$ Mereka berpendapat terutama dari golongan Syi'ah Ismailiyah bahwa Ali hingga kini masih hidup, bukan terbunuh. Sebab Ali telah dikaruniai sifat-sifat ke-Tuhanan yang tak akan pernah mati, bahkan dianggapnya sebagai Tuhan. ${ }^{33}$ Anggapan Syi'ah lainnya mengatakan bahwa roh itu dapat berpindah dari tubuh yang satu ke tubuh yang lain. Dan Allah itu berjisim serta dapat menjelma ke dalam tubuh manusia. Dari pendapat ini nampaknya Syi'ah dalam hal anthropomorphisme sangat dekat dengan pengaruh Hindhu, sedangkan mensifatkan Ali dengan sifat ke-Tuhanan sangatlah dekat dengan faham agama Masehi.

\section{Pendapat Aliran Jabariyah}

Pandangan Jabariyah terhadap faham anthropomorphisme bahwa, Tuhan tidaklah mempunyai sifat, tetapi hanya mempunyai Zat. Tuhan tidak layak disifati dengan sifat mahluk-Nya, sebab yang demikian berarti mentasybihkan (menyerupakan) Tuhan dengan mahluk-Nya. ${ }^{34}$ Jaham bin Abi Sofyan berpendapat bahwa Tuhan sekali-kali tidak mungkin dapat dilihat oleh manusia di akhirat kelak. Dan tentang keberadaan syurga-neraka, setelah manusia mendapatkan balasan di dalamnya, akhirnya lenyaplah syurga dan neraka itu .

\section{Pendapat Aliran Mu'tazilah}

Pandangan Mu'tazilah terhadap faham Mujassimah (anthropomorphisme), mereka menolak dengan keras. Mengenai ayat-ayat al-Qur'an yang mensifati Tuhan dengan sifat-sifat manusia, seperti : Yadullah (tangan Allah), Kalamullah (perkataan Allah), dan sebagainya, haruslah ditakwilkan secara majazi (metafora atau kiasan). Kalamullah tersebut tidak ada pada Zat Tuhan, melainkan berada di luar diri-Nya. Mu'tazilah tidak mengakui adanya sifat-sifat Tuhan sebagi suatu yang qadim, juga

${ }^{32}$ Lihat M.H. Thaba Thaba'i, Shi'ie Islam, di terjemahkan oleh Djohan Efendi dengan judul, Islam Syi'ah : Asal Usul dan Perkembangannya ( Cet. ke- 2 ; Jakarta : Pustaka Utama Grafiti, 1983), h. 37.

${ }^{33}$ Lihat As - Syahrastani, al- Milal wa al- Nihal, Jilid I ( Cet. Ke- 2; al-Misriyah : Maktabah El-Englo, 1956 ), h. 193.

${ }^{34}$ Lihat Taib Thakhir Abd. Mu'in, Ilmu Kalam ( Cet. Ke- 8; Jakarta : Penerbit Wijaya, 1980 ), h. 92. 
mengingkari adanya faham bahwa, Tuhan nanti dapat dilihat oleh manusia dengan mata kepala di akhirat kelak. ${ }^{35}$ Alasan Mu'tazilah dalam masalah melihat Tuhan ini nampaknya cukuplah rasional, dimana Tuhan adalah bersifat Immateri, sedang mata kepala adalah bersifat materi. Sehingga tidaklah mungkin suatu yang immateri dapat dilihat dengan suatu yang materi.

\section{Pendapat Aliran Al-Asy'ariyah}

Pandangan Al-Asyi'ariyah dalam hal anthropomorphisme di antaranya meliputi :

a. Tentang Melihat Tuhan (Ru'yah Allah )

Dalam masalah melihat Allah, al-Asyi'ary berpendapat bahwa Allah Swt. dapat dilihat oleh hamba-hamba-Nya yang beriman di akhirat kelak seperti halnya mereka melihat bulan purnama. Al-Asyi'ary berpendapat bahwa segala sesuatu yang ada (maujud) memungkinkan untuk dapat dilihat, karena Allah adalah sesuatu yang maujud maka sah untuk dilihat (sebagaimana dijelaskan dalam al-Qur'an Surat al-Qiyamah (75) : 22). ${ }^{36}$

b. Tentang Tasybih dan Tajsim ( Penyerupaan dan Personifikasi )

Al-Asyi'ary sangatlah hati-hati terhadap masalah tasybih (penyerupaan dengan mahluk), hal ini dapat dilihat pernyataan al-Asyi'ari dalam kitab "al- Luma' “ sebagaimana dikutip oleh H.M. Laily Mansur : "Ketika engkau menyatakan bahwa Tuhan tidak menyerupai seluruh mahluk, maka katakanlah bahwa sekiranya Tuhan menyerupai -Nya, tentulah hukumnya sama dengan hukum hadis (yang baru), jika diserupakan, maka tidak terlepas dari keseluruhan atau sebagiannya. Jika keseluruhan, maka keadaannya sama dengan hadis keseluruhan, dan jika sebagian, maka keadaannya serupa untuk sebagian dengan yang hadis (baharu), yang demikian itu semuanya mustahil bagi Zat yang Qadim. ${ }^{37}$ Dengan demikian al-Asyi'ary dalam menetapkan sifat-sifat Tuhan adalah tanpa melalui ta'wil maupun tasybih.

${ }^{35}$ Lihat A. Hanafi, Pengantar Theologi Islam ( Cet. Ke- 2 ; Jakarta : Pustaka al-Husna, 1980 ), h. 77.

${ }^{36}$ Lihat As - Syahrastani, al- Milal ..., h. 87.

37 Lihat H.M. Laily Mansur, Pemikiran Kalam Dalam Islam ( Cet. Ke- 1 ; Jakarta : Pustaka Firdaus, 1994 ), h. 62. 


\section{Pendapat Aliran al-Maturidiyah}

Pandangan Aliran Maturidiyah tentang anthropomorphisme sependapat dengan al-Asyi'ary, bahwa Tuhan dapat dilihat dengan mata kepala di akhirat kelak. Bagi al-Maturidy yang tidak dapat dilihat hanyalah yang tidak mempunyai wujud, yang mempunyai wujud mesti dapat dilihat. Tuhan adalah berwujud, oleh karena itu dapat dilihat. ${ }^{38}$

Pandangan ini didasarkan pada al-Qur'an surat : al-Qiyamah ( 75 ) ayat : 2223 yang artinya : "Wajah-wajah (orang - orang mukmin) pada hari itu berseri-seri. Kepada Tubanyalah mereka melihat'.

Tentang melihat Tuhan, Maturidi sependapat dengan al-As'ari, akan tetapi mengenai tajassum ia lebih cenderung kepada muktajilah. Al-Maturidy berpendapat bahwa Tuhan sama sekali tidak mempunyai badan dan jasmani. ${ }^{39}$ Menurutnya tenaga, wajah, dan sebagainya mesti di beri arti majazi atau kiasan, seperti tangan Tuhan harus ditakwilkan dengan kekuasaan Tuhan .

Dari pandangan ini terlihat bahwa dalam aspek pemikiran tertentu alMaturidy sependapat dengan Mu'tazilah, pada aspek lain ia bisa satu pandangan dengan as-Ariyah.

\section{Pendapat Aliran Salaf}

Aliran Salaf dalam menetapkan sifat-sifat Tuhan, nama-nama atau perbuatan Tuhan yang termuat dalam al-Qur'an dan al-Hadis, seperti : alHayyu (yang hidup), al-Qayyum (yang tidak membutuhkan yang lain), alShamadu (yang dibutuhkan oleh yang lain), Zul 'Arsy al-Majid (yang mempunyai arsy yang megah), Tuhan turun kepada manusia dalam gumpalan awan (baca al-Baqarah : 210), Tuhan bertempat di langit (baca QS. Fushilat: 11), Tuhan mempunyai muka (baca QS. Al-Baqarah : 115), Tuhan mempunyai tangan (baca QS. Ali Imran : 73) dan seterusnya. $^{40}$

38 Lihat Abui Hasan Ali bin Ismail al-Asy'ary, Al-Ibanah an Ushul al-Diyanah( Madinah: al- Jami'ah al-Islamiyah Markaz Su'untuk al-Dakwah, 1409 ), h. 16.

${ }^{39}$ Lihat Abu al-Yusr Muhammad bin Muhammad Abd. Karim al-Bazdawy, Kitab Ushul al Din (Qairo : Isa al-Babi al-Halabi, 1963 ), 27.

40 Ibid, h. 139. 


\section{Pandangan Kaum Sufi}

Dengan penuh keyakinan para sufi menganggap bahwa Tuhan adalah realitas yang zahir dan immanen meski pada sisi lain dia bersifat batin dan transenden. Meskipun Tuhan tersembunyi (batin) dan "jauh" (transenden) tidak membuat kaum sufi merasa Tuhan begitu jauh dan tak terjangkau sebagaimana yang dikonsepsi oleh para filosof. Para sufi lebih menekankan pandangan Tuhan begitu "dekat" dan "menyatu" (immanen) dengan makhlukNya. Hal ini sebagaimana yang diungkapkan oleh Imam Ali bin Abi Thalib, ketika ia ditanya, "mengapa engkau menyembah Tuhan yang tak kau lihat"?. Imam Ali menjawab; "bagaimana mungkin aku menyembah Tuhan yang tak aku lihat? Aku melihat Tuhan yang aku sembah, tapi aku tidak melihat dengan mata lahirku, melainkan dengan mata batinku". Dalam keempatan lain Imam Ali bin Abi Thalib mengatakan, "aku melihat Tuhan sebelum, pada saat, dan sesudah melihat sesuatu".

Syeikh Junaid terkenal sebagai seorang yang amat waro' (tekun ibadat), seorang Waliyullah, seorang Shufi besar pada zamannya, yang tetap teguh memegang syariat. Banyak sekali tokoh-tokoh Shufi besar adalah murid-murid beliau. Antara lain, Abu 'Ali Ad-Daqaq, Abu Bakar Al-Atthar, AlJurairi, 'Athowi dan lain-lain. Diceritakan saat beliau mendekati akhir hayatnya, secara terus menerus mendirikan sembahyang dan membaca Al-Qur'an. Beliau wafat pada hari Jum'at tahun 297 Hijriyah, setelah selesai membaca ayat ke 70 Surat. Al-Baqarah.

Sehubungan dengan ucapan beliau tentang Tuhan, murid beliau bertanya :"Ya Abal Qosim, apakah engkau dapat melihat Tuhan pada waktu engkau menyembah-Nya ? Beliau menjawab : "Kami (Para Arif) tidak akan menyembah-Nya bila kami tidak melihat-Nya. Kami juga tidak akan bertasbih untukNya bila kami tidak mengenal-Nya". 


\section{E. Kesimpulan}

Berdasarkan penjelasan di atas maka dapat ditarik kesimpulan dari makalah antropomorfisme ini sebagai berkut :

Bahwa antropomorfisme secara doktrinal merupakan kemestian dan nyata adanya baik di dalam hadist maupun al-Quran. Jumlahnyapun sangat banyak, bisa mencapai ratusan. Dari hadis rasulullah tersebut ditemukan riwat-riwat yang sohih yang diriwatkan oleh Bukhori dan Muslim. Bila dilihat dari Mukhorrij tersebut sangat diyakini bahwa hadist tersebut sangatlah benar, dan tiada nalar untuk menolaknya.

Sedangkan pada tataran pemikiran, baik di sarah maupun pendapat ulama, teolog dan sufi didapatkan pemikiran mereka beragam. Masing-masing mengemukakan argumentasi yang mendukung pemikiran mereka. Tiada satupun yang bisa diutamakan melebihi yang lainnya, sebab semua interpretasi itu tujuannya untuk membangun keimaan yang benar kepada Allah SWTT. Wallohu a'lam bis showab. 


\section{DAFTAR PUSTAKA}

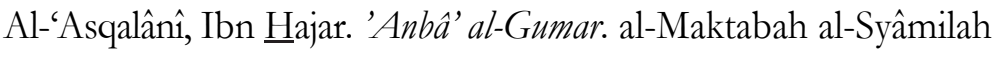

Al-'Asqalânî, Ibn ㅂajar. Fath al-Bârî, Juz I. Kairo: Dâr al-Fikr 1383 H.

Al-'Asqalânî, Ibn Hajar. Hady al-Sâri, Muqaddimah Fath al-Bârî. Kairo: Dâr al-Fikr,

Al-'Asqalânî, Ibn Hajar. Raf' al-Ishr 'an Qudhah Mishr. Qaherah: al-Matba'ah al Âmiriyyah, t.t.

Al-Bukhârî. Shahîh al-Bukhârî, Juz XXII. Beirut: Dâr Kutub 'Ilmiyah, 1974.

Al-Fadhl, Abû. Diwân Ibn Hajar al'AAsqalânî. Beirut: Dâ'irah al-Ma'ârif al-'Usmâniyyah, 1962.

Al-Manâwi, 'Abd al-Ra'ûf. al-Yawâqit wa al-Durar fí Syarb Nukbbab Ibn Hajar. al-Maktabah alSyamilah, t.t.

Al-Sakhâwî, al-Daw'al-Lâmi’. al-Maktabah al-Syamilah, t.t.

Al-Sakhâwî, al-Jawâhir wa al-Durar, fî Tarjamah Syaikh al-Islâm Ibn Hajar al-'Asqalânî,Cet. 2. Qâhirah: Majlis al-A'lâ li al-Syû'un al-Islâmiyyah, t.t.

Al-Suyûthi, Tadrîb al-Rawñ fî Syarh Taqrîb al-Nawawî. Madinah al-Munawarah: Maktabah alIlmiyyah, t.t.

Al-Syaikh, Shalîh Alu. Ittihaf al-Sa îl bima fí al-Thâhawiyah min Masẩil, Juz I. al-Maktabah alSyâmilah, t.t.

Al-Syaikh, Shâlih Alu. Syarh Aqîdah al-Thahawiyah. t.t.p.: t.p., t.t.

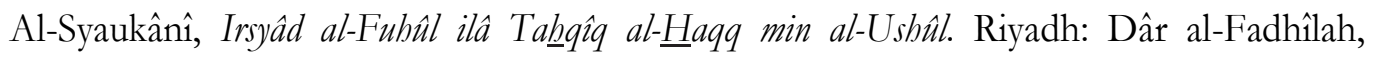
2000.

Al-Syibli, 'Ali ibn 'Abdil 'Azîz ibn 'Alî. al-Tanbîh 'Alâ al-Mukhâlifat al-'Aqîdah fî Fath al-Bârî. t.t.p.: t.p., t.t.

Hitti, Philip K. History of the Arabs. London: McMillan Publishing, 1970.

Ibn 'Abdillâh, Yâqût Hamâwî. Mu'jam al-Buldân, Juz IV. Beirut: Dâr Ihya' Turasy al-'Arabî, 1979.

Ibn Khaldûn. Muqaddimah. Beirut: Dâr al-Jayl, t.t.

Lewis, Bernard, et al. The Encyclopedia of Islam, Vol. III. London: 1986.

Lorens Bagus, Kamus Filsafat, Jakarta, Gramedia, 1996 
Nasution, Harun. Teologi Islam: Aliran-aliran, Sejarah, Analisa Perbandingan. Jakarta: UI Press, 1986.

Ziriklî, Khair al-Dîn. Al-A lâm, Qâmus Tarâjum Li asyhur al-Rijâl wa al-Nisâ min al-'Arab wa alMusta'ribîn wa al-Mustasyriqîn, Juz I. Beirut: Dâr al-'Ilm li al-Malayin, 1974.

Yusuf Qardhawi, Bagaimana Memahami ḥadiṡ Nabi SAW, Bandung : Karisma, 1993 